\title{
Chemical and Spectra Studies of the Alleged Killer Seed of Berlinia grandiflora
}

\author{
Duru C.E. ${ }^{1}$, Duru I.A. ${ }^{2}$, Ikpa C.B.C ${ }^{3}$ and Ibe F.C. ${ }^{3}$ \\ ${ }^{I}$ Department of Chemistry, Alvan Ikoku Federal College of Education Owerri, Imo State Nigeria \\ ${ }^{2}$ Department of Chemistry, Federal University of Technology Owerri, Imo State Nigeria \\ ${ }^{3}$ Department of Chemistry, Imo State University Owerri, Nigeria
}

\begin{abstract}
The aqueous extract of the seed of Berlinia grandiflora was analyzed for toxic phytochemicals. Alkaloid, saponin, tannin, flavonoid and starch were detected in the photochemical screening of the extract. The GC/MS studies showed that the extract contained pentadecanoic acid (15\%), 9-octadecenamide (16\%), octadecanoic acid (17\%), $\alpha$-methyl-mannofuranocide $(21 \%)$ and 9-octadecenoic acid $(31 \%)$. Some of the important functional groups in the compounds were further confirmed using FTIR. The presence of toxic phytochemicals that can lead to instant death were not evident from the results of this studies. However, the high concentration of fatty acids in the extract can cause metabolic acidosis which can lead to severe diarrhea in humans.
\end{abstract}

Keywords:Berlinia grandiflora, diarrhea, fatty acids, metabolic acidosis, phytochemicals

\section{Introduction}

Berlinia grandiflora is a forest tree that is sometimes planted as ornamental tree and shade tree in villages and coffee plantations. It is occasionally browsed by livestock especially sheep and goats. It is widespread in Guinea, Mali, Nigeria, Central Africa and Democratic Republic of Congo [1]. The Igbos of south eastern Nigeria refer to it in their local languages as ububa while the Yorubas of the south west refer to it as apado [1].

The bark sap is applied to sores and wounds, and bark decoctions are administered to treat hemorrhoids and liver problems [2]. A decoction of the leafy twigs is used as febrifuge and antiemetic while leafy decoctions are taken as tonic [2]. The analgesic activity of the stem bark extract has been reported [3]. Also the leaf and stem bark extracts have been shown to have appreciable antimicrobial $[4]$ and antihelminthic properties $[5,6]$.

Between the months of May and July 2013 in Imo State south eastern Nigeria a trail of deaths were reported to have occurred as a result of the consumption of a popular delicacy called 'Ugba' the main food material being oil bean $[7,8]$. According to these reports the cause of death was allegedly ascribed to the dubious mixture of the oil bean with the seed from the plant Berlinia grandiflora which has close resemblance to oil bean seed.

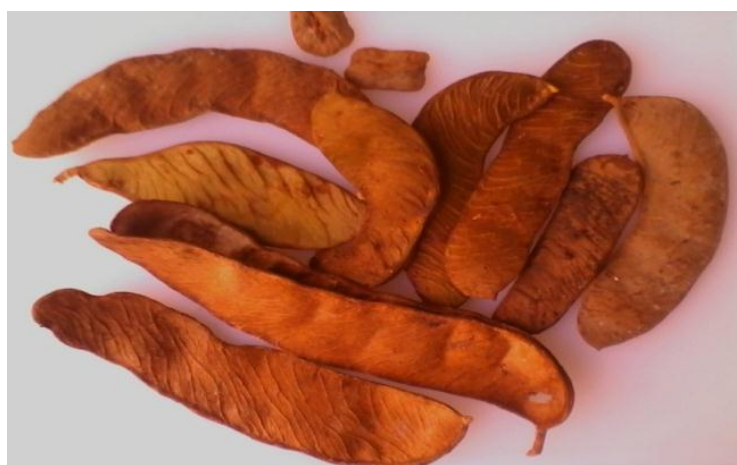

Figure 1: Picture showing the dried pods and seeds of Berlinia grandiflora

Research reports on the phytochemical and possible medicinal uses of this seed or its extracts are scarce. In other to shade light on its phytochemical characteristics and also assert the claim on its toxicity, this study would screen the phytochemicals present in the aqueous extract of the seed of Berlinia grandiflora as well as the spectophotometric characterization of the same extract in an attempt to discover possible toxic compounds that can dissolve in the aqueous human system as alleged. 


\section{Materials And Method}

\subsection{Collection and Identification of Seed}

The fresh and mature pods of the plant were collected in July, 2013 from a mature tree in Ngali village, Logara autonomous community in Ngor Okpala Local Government Area, Imo State, Nigeria. Identification and authentication was done at the Forestry Department of the Federal University of Technology Owerri, Imo State Nigeria.

\subsection{Aqueous Extraction}

The seeds were carefully separated from the woody pod and cut into small bits with a clean knife. The pieces were pulverized using a motar. $100 \mathrm{ml}$ distilled water was used to wash the motar and its content into a $250 \mathrm{ml}$ flask which was covered with cellophane and heated in a shaker water bath for 1 hour at $100{ }^{\circ} \mathrm{C}$. The beaker and its content were allowed to cool and the resulting mixture was filtered. The filtrate was reduced to 50 $\mathrm{ml}$ by heating over a water bath at $70{ }^{\circ} \mathrm{C}$. Aliquots of this solution were taken for FTIR and Gas Chromatography/Mass Spectrophotometric studies while the remaining solution was screened for phytochemicals.

\subsection{Phytochemical Screening}

Screening of the filtratefor possible toxic phytochemicals was carried out as described by Tiwari et al [9], Harborne [10], Trease and Evans [11] and Sofowora [12].

\subsubsection{Test for Alkaloids}

Wagner's Test: Filtrates were treated with Wagner's reagent (Iodine in Potassium Iodide). Formation of brown/reddish precipitate indicates the presence of alkaloids.

\subsubsection{Test for Saponins}

Foam Test: $0.5 \mathrm{gm}$ of extract was shaken with $2 \mathrm{ml}$ of water. If foam produced persists for ten minutes it indicates the presence of saponins.

\subsubsection{Test for Phenols}

Ferric Chloride Test: Extracts were treated with 3-4 drops of ferric chloride solution. Formation of bluish black colour indicates the presence of phenols.

\subsubsection{Test for Tannins}

$2 \mathrm{ml}$ of extract was mixed with water and heated on a water bath. The mixture was filtered and ferric chloride was added to the filtrate. A dark green solution indicates the presence of tannins.

\subsubsection{Test for Flavonoids}

Lead acetate Test: Extracts were treated with few drops of lead acetate solution. Formation of yellow colour precipitate indicates the presence of flavonoids.

\subsubsection{Test for Starch}

Iodine Test: Extract was treated with few drops of Iodine-KI solution. Formation of a deep blue solution indicates the presence of starch.

\subsubsection{Test for Cyanogenic Glycosides}

Cyanogenic glycosides were detected using the technique of the picrate-impregnated paper. The assay was performed in triplicate. Fresh plant material was cut into small pieces and placed in a test tube with $1.5 \mathrm{~mL}$ of distilled water, and 6 drops of chloroform, followed by briefly crushing the material with a glass rod. The tube was stoppered with a cork containing a strip of picrate-impregnated paper hanging down from the stopper, and incubated at ambient temperature for $2 \mathrm{~h}$. A colour change of the paper, from yellow to brown-red, indicated the release of $\mathrm{HCN}$ by the plant. If there was no release of $\mathrm{HCN}$ within $2 \mathrm{~h}$, indicating a negative test, the tube was left at ambient temperature for $48 \mathrm{~h}$, so that it could be re-examined. A brown-red coloration within $2 \mathrm{~h}$ indicated the presence of cyanogenic glycoside and the respective hydrolytic enzyme, and the plants were considered cyanogenic in the field. A brown-red colour appearing within $48 \mathrm{~h}$ indicated that the cyanogenic glycoside spontaneously released $\mathrm{HCN}$ without the action of enzyme. 


\subsubsection{Test for Anthraquinones}

Borntrager's test: $5 \mathrm{ml}$ of chloroform was added into $2 \mathrm{ml}$ of extract and the mixture shaken for about 5 minutes. It was filtered and the filtrate shaken with equal volume of $10 \%$ ammonia solution. A pink-violet or red colour in the ammoniacal layer (lower layer) indicates the presence of anthraquinones.

\subsubsection{Test for Terpenoids}

Salkowski test: $2 \mathrm{ml}$ of the extract was mixed with $2 \mathrm{ml}$ of chloroform and $3 \mathrm{ml}$ of concentrated sulphuric acid was carefully added to form a layer. A reddish brown colouration of the interface was formed to indicate the presence of terpenoids.

\subsubsection{Test for Steroids}

$2 \mathrm{ml}$ of acetic anhydride was added to $2 \mathrm{ml}$ of the extract followed by $2 \mathrm{ml}$ of $\mathrm{H}_{2} \mathrm{SO}_{4}$. Colour change from violet to blue, or green in some samples indicate the presence of steroids.

\subsection{Spectrophotometric Analysis}

The functional group properties of the aqueous extract was analysed using Perkin Elmer Spectrum BX FTIR Spectrophotometer while the molecular structures of the phyto components were determined using GCMS-QP2010 PLUS.

\section{Results And Discussion}

The results of the phytochemical screening of the brown, viscous aqueous seed extract are shown in table 1 .

Table 1: Phytochemistry of aqueous extract of the seed of Berlinia grandiflora

\begin{tabular}{|l|l|l|l|l|l|l|l|l|l|}
\hline Phytochemical & Alkaloid & Saponin & Phenol & Tannin & Flavonoid & Steroid & Anthraquinone & $\begin{array}{l}\text { Starch } \\
\text { Cyanogenic } \\
\text { glycoside }\end{array}$ \\
\hline Presence & ++ & ++ & - & ++ & ++ & - & - & + \\
\hline
\end{tabular}

Key - Present in low concentration (+); Present in moderate concentration (++); Absent $(-)$

The results obtained showed the presence of alkaloid, saponin, tannin, flavonoid and starch.

The FTIR and GCMS scans of the aqueous extract of Berlinia grandiflora seed is shown in fig. 2 and fig. 3.

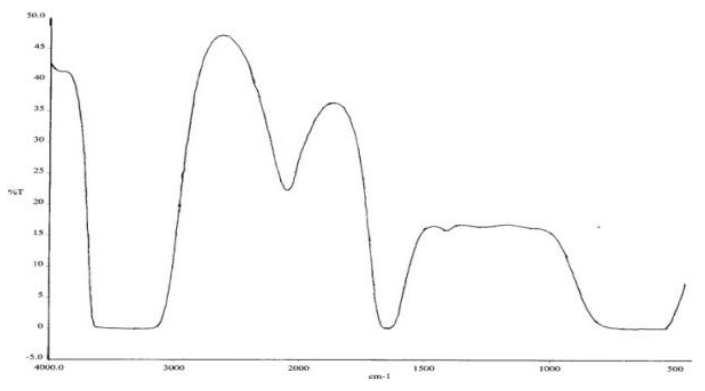

Figure 2: FTIR scan of aqueous extract of Berlinia grandiflora seed

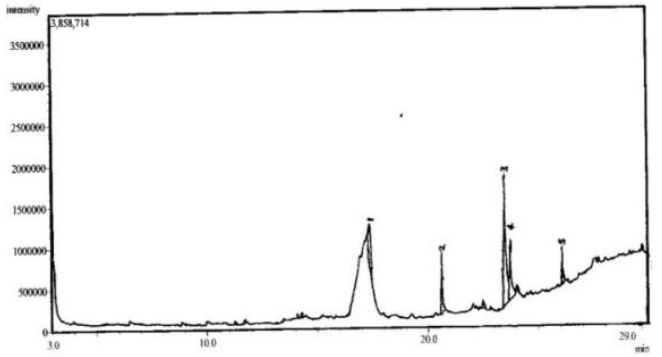

Figure 3: Gas chromatogram of aqueous extract from the seed of Berlinia grandiflora 
The chromatogram showed the presence of five main compounds in the extract which according to their increasing concentrations are pentadecanoic acid (15\%), 9-octadecenamide (16\%), octadecanoic acid (17\%), $\alpha$-methyl-mannofuranocide $(21 \%)$ and 9-octadecenoic acid $(31 \%)$. The mass spectrophotometric scan predicted their structures and the data obtained are summarized in table 2 .

Table 2: Summary of mass spectrophotometry results from the aqueous extract of the seed of Berlinia grandiflora

\begin{tabular}{|c|c|c|c|c|c|c|}
\hline Compounds & Name & $\begin{array}{l}\text { Molecular } \\
\text { weight }\end{array}$ & Formular & $\begin{array}{l}\text { Retention } \\
\text { time }\end{array}$ & $\begin{array}{l}\% \\
\text { content }\end{array}$ & $\mathrm{m} / \mathrm{z}$ fragment \\
\hline 1 & $\begin{array}{l}\alpha \text {-methyl- } \\
\text { mannofuranocide }\end{array}$ & 194 & $\mathrm{C}_{7} \mathrm{H}_{14} \mathrm{O}_{6}$ & 17.392 & 21 & $\begin{array}{l}194(0.5 \%), 163(20 \%), 145(10 \%), \\
116(40 \%), 73(100 \%)\end{array}$ \\
\hline 2 & Pentadecanoic acid & 242 & $\mathrm{C}_{15} \mathrm{H}_{30} \mathrm{O}_{2}$ & 20.633 & 15 & 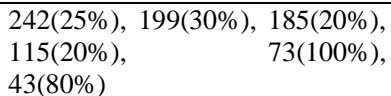 \\
\hline 3 & 9-octadecanoic acid & 282 & $\mathrm{C}_{18} \mathrm{H}_{34} \mathrm{O}_{2}$ & 23.483 & 31 & $\begin{array}{lr}282(10 \%), & 264(40 \%), \\
223([\mathrm{M}+1]=0.5 \%), & 97(50 \%), \\
83(70 \%), 69(80 \%), 43(70 \%)\end{array}$ \\
\hline 4 & Octadecanoic acid & 284 & $\mathrm{C}_{18} \mathrm{H}_{36} \mathrm{O}_{2}$ & 23.733 & 17 & $\begin{array}{l}284(40 \%), 241(20 \%), 227(5 \%), \\
185(25 \%), 171(10 \%), 129(50 \%), \\
98(25 \%)\end{array}$ \\
\hline 5 & 9-octadecinamide & 281 & $\mathrm{C}_{18} \mathrm{H}_{35} \mathrm{NO}$ & 26.075 & 16 & $\begin{array}{l}281(20 \%), \\
126(15 \%), \quad 140([\mathrm{M}+1]=5 \%), \\
112(10 \%), 98(10 \%)\end{array}$ \\
\hline
\end{tabular}

The presenceof starch and an amide were further confirmed from the functional group vibrational frequencies obtained in the FTIR data, which gave a strong and broad peak at $3300 \mathrm{~cm}^{-1}$ showing -OH group from glucose and a strong absorbance at $1640 \mathrm{~cm}^{-1}$ showing an amide carbonyl from 9-octadecenamide, a fatty acid amide. Phytochemical screening tests did not detect the presence of any commonphytotoxic compound in the extract. The composition of the aqueous extract of the seed of Berlinia grandiflora from the GCMS can be grouped as $21 \%$ sugar (mannofuranocide) $16 \%$ fatty acid amide and $63 \%$ fatty acids. 9-octadecenamide or oleamide is an amide of oleic acid which occurs naturally in the body of animals [13] and could not have been responsible for the possible toxic property of the seed.The extract also contains 9-octadecenoic acid or oleic acid (31\%). Oleic acid which is a common monounsaturated fat in human diet [14] can hinder the progression of adrenoleukodystrophy which is a fatal disease that affects the brain and adrenal gland [15]. It is also administered in the reduction of high blood pressure in humans [16]. The high concentration of fatty acids in the extract however can cause metabolic acidosis which can lead to severe diarrhea or renal insufficiency in human beings [17].

\section{Conclusion}

The aqueous extract of Berlinia grandiflora seed was found to have saturated and monounsaturated fatty acids. The high concentration of fatty acids in this extract when in contact with the human aqueous system can lead to severe diarrhea. The fatality of this diarrhea however is not known within the limits of this work. The severe diarrhea reported after the consumption of the delicacy alleged to have been mixed with the seed of Berlinia grandiflora is possible from our findings. This situation leading to the death of another group of consumers is not evident from the data obtained from chemical and spectra studies of aqueous seed extract.

\section{References}

[1] J. Hutchison and J.M. Dalziel, Flora of West Africa, Vol. II(London University press, London, 1963$), 74$.

[2] L.S. Gill, Ethnomedicinal uses of plants in Nigeria,(University of Benin press, Nigeria, 1992), 65.

[3] J.U. Asuzu, O.C. Nwele and A.O. Anaga, The pharmacological activities of the stem bark methanolic extract of Berlinia grandiflora, Fitoterapia, 64(6), 1993, 529-534.

[4] C. Godwin,A. Josephs, P. Fidelis,B. Ching and A. C. Nnabuife, Investigation of the antimicrobial potentials ofsome phytochemical extracts of leaf and stembark of Berlinia grandiflora (Leguminoceae) Caesalpinioidae against pathogenic bacteria, African Journal of Pharmacology and Therapeutics1(3), 2012, 92-96.

[5] N.M. Enwerem, C.O. Wambebe, J.I. Okogun, P.A. Akah and K.S. Gamaniel, Antihelminthic screening of stem bark of Berlinia grandiflora, J. Nat. Remed., 1, 2001,17-20.

[6] N.M. Enwerem, J.I. Okogun, C.O. Wambebe, D.A. Okorie and P.A. Akah, Antihelminthic activity of the stem bark extracts of Berlinia grandiflora and one of its principles betulinic acid, Phytomed.,8, 2001,112-114.

[7] Daily Independence Newspaper, Egbelu Nguru: Imo community in the throes of unusual death, June 112013.

[8] Vanguard Newspaper, 30 hospitalized after eating Ugba - At child dedication, July 82013.

[9] P. Tiwari, B. Kumar, M. Kaur, G. Kaur, H.Kaur, Phytochemical Screening: A Review,InternationalePharmaceuticaSciencia,1(1), 2011,103-104.

[10] J.B. Harborne, Phytochemical Methods, ( $3^{\text {rd }}$ Edition, Chapman and Hill Ltd, London, 1973) 135- 203.

[11] G.E. Treaseand W.C. Evans, Pharmacognosy, $\left(11^{\text {th }}\right.$ Edition, Brailliar Tiridel and Macmillian Publishers, London, 1989). 
[12] A. Sofowora, Medicinal Plants and Traditional Medicine in Africa,(John Wiley and Sons Ltd., 1993) 150-153.

[13] B.F. Cravat, O. Prospero-Garcia, G. Siuzdak, N.B. Gilula, S.J. Henriksen, D.L. Boger and R.A. Lerner, Chemical characterization of a family of brain lipids that induce sleep, Science, 268(5216), 2008, 1506-1509.

[14] A.J. Vergroesen and M. Crawford, The role of fat in human nutrition, $2^{\text {nd }}$ Edition, (Academic Press London, 1989) 49-79.

[15] W.B. Rizzo, P.A. Watkin, M.V. Philips, D. Cranin, E. Campbell and J. Avigan, Adrenoleucodystrophy: Oleic acid lower fibroblast saturated $\mathrm{C}_{22}-\mathrm{C}_{26}$ fatty acid,Neurology, 36(3), 1986, 357-361.

[16] A. Alonso and M.A. Martinez-Gonzalez, Olive oil consumption and reduced incidence of hypertension: The SUN study, Lipids,39, 2004, 1233-1238.

[17] L.S. Goodman and A. Gitman, The Pharmacological Basis of Therapeutics, $5^{\text {th }}$ Edition, (Macmillan Publishing Company, New York, 1975), 773. 